\title{
The Effect of an Acquirer's Life Cycle Stage on the Performance of M\&As: Evidence from Mega and Non-Mega Deals in the US
}

\section{Svetlana Grigorieva}

$\mathrm{PhD}$, researcher, associate professor

$\underline{\text { ORHID }}$

E-mail: svetlanaagrigorieva@gmail.com

School of Finance, NRU HSE, Moscow, Russia

\section{Angelina Egorova}

Graduate from master program "Strategic Corporate Finance",

$\underline{\text { ORCID }}$

E-mail: volosevich.angelina@gmail.com

NRU HSE, Moscow, Russia

Journal of Corporate Finance Research, Vol. 13, No. 3, pp. 7-18 (2019)

DOI: $10.17323 /$ j.jcfr.2073-0438.13.3.2019.7-18

Received 15 July 2019 | Peer-reviewed 10 August 2019 | Accepted 3 September 2019 


\section{The Effect of an Acquirer's Life Cycle Stage on the Performance of M\&As: Evidence from Mega and Non-Mega Deals in the US}

\section{Abstract}

A substantial body of academic literature continues to investigate whether M\&A deals create or destroy shareholder value and what are the main determinants of M\&A performance, but the results are still inconclusive. In this paper, we investigate the impact of corporate life cycle on M\&A performance from the perspective of acquiring firms.

We shed additional light on the performance of M\&A deals from the perspective of bidders' life cycle stages and the deal size. We single out mega deals, where activity remains upbeat, and compare their effects on M\&A performance with the effect of non-mega transactions. In contrast to previous studies in the area, we identify four life cycle stages (introduction, growth, maturity and decline), whereas the existing literature mostly focuses on three life cycle stages.

Our sample includes 2413 US domestic M\&A deals from 2003 to 2017, and consists of 386 mega deals and 2027 nonmega transactions. The data for analysis were obtained from Capital IQ, Bloomberg and Thomson Reuters Eikon databases.

Based on the event study method and regression analysis, we find that stock market reaction is positive for M\&A deals in the US and this reaction is more favourable for non-mega acquisitions than for mega M\&A deals. We show that nonmega deals outperform mega transactions for acquirers at the introduction and growth stages of the business life cycle. Our results also indicate that benefits for shareholders from acquiring firms decrease on average with the lifecycle of an organisation, but the returns for shareholders are positive in both cases. By contrast, in mega deals, shareholders receive negative returns when the acquiring firm is at introductory life cycle stage.

The scientific novelty of this paper is reflected in our contribution and expansion of the scope of research in this field. There is a relative scarcity of analysis examining M\&A deals from the perspective of life cycle stage, and our addition of a fourth category of analysis in this area, along with a focus on the value of the deal, expands the range of methodology for future research. This research is open to further expansion in different markets and our methodology is readily adaptable for the addition of further analytical variables. Importantly, with the validation of our research hypotheses and the confirmation of significant results, we provide a useful new tool for managers and professionals engaged in M\&A deals to actively gauge and forecast practical implications of their deals.

Keywords: Mergers and Acquisitions, Value Creation, Life Cycle of organisation (LCO), Life Cycle stage, Mega deals JEL-classification: G34, G14 


\section{Introduction}

The rise in M\&A activity over the past several decades has led to levels of intense research into M\&A impact on company performance. Within this context, debates touch two main issues: whether M\&A deals create or destroy firm value, and what are M\&A performance drivers. However, empirical evidence on these questions remains controversial and inconclusive.

One possible explanation for the observed ambiguity in research findings suggest that M\&A performance and its determinants vary according to a company's organisational (or corporate) life cycle (LCO). Researchers have analysed various aspects within the organisational life cycle framework. However, studies of the impact on M\&A performance are limited. As far as we know, there are no investigations on deal performance determinants across different stages of LCO. Indeed, life cycle seems to play a crucial role in M\&A outcomes. Across life cycle stages, firms demonstrate particular financials, strategies, and organisational structure. Thus, a company's financial and non-financial features change with LCO stages, which may potentially affect both M\&A performance and its determinants.

There are only a few studies which explore the relevance of LCO to M\&A performance. Owen and Yawson (2010) reveal that cumulative abnormal returns (CARs) levels in US deals decline over the course of the corporate life cycle, while Arikan and Stulz (2016) prove this effect only for private M\&As [1;2]. Chuang (2017) claims that financial advisors can bring higher returns to growing and mature companies, while there is no reward for firms at the stage of stagnation [3].

In this paper we expand the discussion of the impact of LCO on M\&A performance in the US and contribute to the existing literature in two ways. First, we separate the acquirer's life cycle into four stages (introduction, growth, mature, decline), whereas previous studies mostly focus on three stages [1-3]. Second, we assess the effect of acquirer's life cycle stage on M\&A performance, controlling for the question as to whether a deal is a mega deal or non-mega one. According to Alexandridis et al. $(2010,2013)$ mega deals destroy value for an acquirer on a greater scale compared to non-mega ones, mostly due to overpayment and difficulties with integration. But these reasons may also depend on the LCO stage of the acquiring company [4; 5].

The remainder of this paper is organised as follows: Section 2 presents the summary of relevant literature and develops testable hypotheses. Section 3 defines the methodology. Section 4 describes the sample selection procedure. Section 5 presents the results, and Section 6 concludes the study.

\section{Literature review and hypotheses Corporate life cycle concept}

The lifecycle of a firm includes the set of break-even moments in the company's business. In particular, across their entire lifecycle, firms face different problems, opportunities, barriers, anomalies and decision types. Given this state of affairs, an analysis of any firm's situation should be applied in relation to the corresponding stage of the lifecycle. It is common to separate the lifecycle into four main stages - introductory, growth, maturity and decline [6;7]. At the introduction stage, the firm experiences lack of knowledge about the industry [8], while excess managerial optimism might lead to quite high investment rates. Additional debt financing may be needed but may not be available due to particular financial constraints. When the company moves to the growth stage, the period of profit margin maximisation starts. The company maximises its cash flows and becomes rich in its own resources, so financial constraints are not the most relevant problem anymore [9]. At the maturity stage a firm already possesses an appropriate level of knowledge regarding the industry, which helps it to boost the efficiency of operations [10]. As the investment rate starts to decline gradually, the necessity of debt financing diminishes over time [9], while owners demand funds to be distributed. Finally, at the decline stage the company's growth rates start to decline and the firm experiences high organisational inertia, becoming very inflexible in terms of decision making $[11 ; 12]$, and the company's assets enter the liquidation process. Thus, companies at different corporate life cycle stages are subject to different decisions, have different opportunities, and operate under different circumstances. Company financial and non-financial features change with LCO stages, which may potentially affect both M\&A performance and its determinants.

\section{LCO effect on M\&A activity and performance}

An analysis of academic and professional literature that connects the corporate life cycle concept and M\&A deals allows for differentiation between two major streams of research. The first examines the impact of an acquirer's LCO stage on the probability it will engage in an M\&A deal. The second stream reveals the effect of an acquirer's LCO stage on M\&A performance.

The research was pioneered by Owen and Yawson (2010), who examined 1,934 US bidders from 1991 till 2005 [1]. The authors identify the LCO stage based on Retained Earnings/Total Assets and Retained Earnings/Total Equity indicators, separating all acquirers into three groups young, mature, and old firms. The results suggest that the probability of M\&A engagement follows an inverted U-shaped pattern over the firm's lifecycle: firms in their early years do not possess the sufficient amount of funds needed for deals while old firms may not be engaged in deals due to high level of inflexibility in the process of undertaking decisions. However, M\&A performance, (approximated by value weighted CAR over $(-2 ;+2)$ and $(-1$; +1 ) windows), demonstrates different dependence on the LCO of an acquirer as abnormal returns due to the deal are negatively related to the lifecycle stage. 
Analysing a more extended sample of US deals from 1981-2012, Arikan and Stulz (2016), in contrast to previous authors, find that the acquisition rate follows a U-shaped pattern over the lifecycle. The authors also state that young firms have higher probability to buy private targets. Using the event study method to assess the performance of M\&A deals, the authors argue that public M\&As are not beneficial at all stages while the wealth effects of private M\&As decline over an acquirer's corporate life cycle stages [2].

The study provided by Partin and Vasin (2014) extends the research to emerging markets, performing an analysis of 6,374 observations from the BRICS group of countries from 2010 till 2013. Antony and Ramesh (1992), applying a more sophisticated ranking approach to the LCO stage identification (3 stages are under consideration - growth, maturity and decline), the authors claim that the probability of being engaged in M\&A deals is lower for mature and declining companies than for growing firms. The authors also discover that the size of a company and its profitability have a positive impact on the probability of being engaged in M\&A deals across the whole lifecycle. The market-to-book ratio and agency costs demonstrates such an effect only in the case of mature companies and leverage only has a negative impact on such probability in the case of growing firms [13].

In contrast to the previous studies Chuang (2017), concentrates on the deals in which the financial advisors are hired. Analysing 919 deals performed in Asia Pacific over 1995-2014, the author claims that financial advisors can bring higher returns to growth and mature companies. Growing companies receive the highest reward for hiring financial advisors, while there is no reward for hiring financial advisors at the stage of stagnation [3].

Overall, the review of corporate life cycle effect on M\&A performance clearly illustrates that there is a potential link between the efficiency of deals and bidder life cycle stages. While research is scarce, the reviewed papers are limited in terms of analysis of particular markets and the presence of methodological drawbacks which do not allow making an exact conclusion on the LCO effect. Thus, the question of association between LCO stages and M\&A performance remains open. Within this environment, there is a call for more detailed research that will broaden our understanding of M\&A performance.

\section{Performance of mega and non-mega deals}

Over the past several years both academic and business researchers have been interested in comparisons of M\&A deal performance concerning mega deals and non-mega transactions. Mega deals are typically defined as deals priced over $\$ 500 \mathrm{mln}-\$ 1$ bln [5]. Business press representatives have already pointed out that these mega deals destroy value for an acquirer on a greater scale compared to non-mega ones. For instance, The Financial Times points out that mega deals destroy value for all deal participants except executives and financial advisors [14].
Willis Towers Watson (2016) reports that mega deals are the only deal type that had negative average return value for acquirers in 2016 [15].

Academia has also provided some empirical evidence on the issue of differences in M\&A performance between mega and non-mega deals. The classical finding here is that mega deals bring significantly lower returns to acquiring shareholders compared to non-mega ones. Alexandridis et al. (2010) and Alexandridis et al. (2013) analyse the US market and come to conclusion that mega deals destroy value, explaining that economic benefits implied in the price paid are often very hard to achieve $[1,2]$. However, the most recent research of Alexandridis et al. (2017 [1]) and Alexandridis et al. (2017 [2]) point out that some positive shift in the performance of US mega deals can be observed, which can be attributed to the changes in corporate governance practices after the 2007-2008 financial crisis [16-18].

There are several reasons that explain these findings. The first one is that such deals tend to imply overpayment. While engaged in a mega deal, an acquirer should conduct deeper analysis, however, managers tend to be overoptimistic and overestimate the future integration benefits. The overpayment can also arise from the large cash flows of an acquiring company, which results in huge investments in the projects with not very high returns. The second group of reasons relates to difficulties in integration: obviously, it is more challenging to integrate a huge company with its own complicated structure, business processes and corporate culture than a small start-up. Considering the foregoing, it is important to differentiate mega and non-mega deals in research with a great number of mega deals in a sample.

The idea of connections between the corporate life cycle concept and whether a mega or non-mega type of a deal applies arises from the intuitive reasons why mega M\&A deals often fail. One of the reasons is possible overpayment. As an acquirer matures, it collects cash flows and become more resource-rich with a need to invest these resources - managers start to build an empire. Thus, more mature companies have a higher probability of overpayment in mega M\&A deals compared to young and growing acquirers who are very constrained in resources due to a need for rapid expansion.

The second reason for the failure of mega deals is the integration challenge. From the corporate life cycle perspective, this reason might be interpreted twofold: managers of acquirers at later corporate life cycle stages are typically more experienced and have a stronger ability to make the integration succeed. By contrast, however, young companies should be more flexible due to lower level of organisational inertia, which can make the integration process more efficient.

Finally, the engagement in mega M\&A deals is perceived as a decision to expand rapidly. The desire to expand can be treated by investors differently from the perspective of stages in the corporate life cycle. For instance, rapid 
expansion for a growing company is more usual than for an introductory one, as a growing acquirer needs to deal with its competitors and create barriers for entry. Also, declining companies may provide a positive signal to investors through their engagement in mega M\&A deals, which implies that the company is willing to perform drastic changes in order to survive.

\section{Hypotheses}

Based on empirical findings and the theoretical premises outlined above, we propose the following hypotheses for testing on a sample of domestic US deals over the time period 2003-2017.

$\mathbf{H} 1$ In mega deals acquirers receive lower returns than in non-mega deals

Following Alexandridis et al. (2010) and Alexandridis et al. (2013) we expect that mega deals tend to destroy value for an acquirer compared to non-mega ones $[4 ; 5]$.

H2.1 At an introduction stage, acquirers receive higher returns at the announcement of a deal, than at a growth stage.

H2.2 At a growth stage, acquirers receive higher returns at the announcement of a deal, than at a maturity stage.

H2.3 At a maturity stage, acquirers receive higher returns at the announcement of a deal, than at a decline stage.

Hypotheses 2.1-2.3 imply that acquirers at later corporate life cycle stages achieve lower returns. Owen and Yawson (2010) and Arikan and Stulz (2016) provide evidence of the proposition that M\&A performance decreases while an acquirer goes through its corporate life cycle stages [1; 2]. Investors believe that at the later corporate life cycle stages, acquirers face a greater challenge in integrating due to increasing organisational inflexibility. Moreover, at the later corporate life cycle stages, the probability of possessing huge excessive cash flows increases, which leads to inefficient investments - managers may start to build an empire without proper analysis of synergies and expected benefits, expressing overoptimism.

H3.1. Mega M\&A deals, in which acquirers are at introduction stage, have a negative impact on acquirers' returns.

H3.2. Non-mega M\&A deals, in which acquirers are at introduction stage, have a positive impact on acquirers' returns.

H4.1. Mega M↔A deals, in which acquirers are at growth stage, have a positive impact on acquirers' returns.

H4.2. Non-mega MઐA deals, in which acquirers are at growth stage, have a positive impact on acquirers' returns.
H5.1. Mega M\&A deals, in which acquirers are at maturity stage, have a negative impact on acquirers' returns.

H5.2. Non-mega M\&A deals, in which acquirers are at maturity stage, have a positive impact on acquirers' returns.

H6.1. Mega MઐA deals, in which acquirers are at decline stage, have a positive impact on acquirers' returns.

H6.2. Non-mega MઐA deals, in which acquirers are at decline stage, have a positive impact on acquirers' returns.

As has already been mentioned, engagement in a mega M\&A deal is perceived as a decision to expand rapidly. The desire of an acquirer to expand rapidly at introductory stage can be perceived as too hasty and as a project for which the company does not possess enough experience. In contrast, rapid expansion for a growing company is more ordinary, at the same time young growing companies should be more flexible due to a lower level of organisational inertia $[11 ; 12]$, which can make the integration process more efficient and successful. However, while an acquirer matures, it collects cash flows, becomes more resource-rich and managers start building an empire, that is the reason why more mature companies have a higher probability of overpayment in mega M\&A deals and might achieve lower returns due to this fact.

\section{Methodology}

Our empirical analysis includes three steps. The first step is identification of an acquirers' corporate lifecycle stages, and differentiation between mega and non-mega deals. Based on the obtained results, the subsamples for further analysis are formed: the whole sample is divided into four subsamples based on acquirer's lifecycle stage and the question as to whether a deal is a mega or a non-mega one. The second step is the estimation of M\&A performance for the full sample and determined subsamples, using a standard event study analysis. We also present a comparative analysis of M\&A deals performance between stages, using $\mathrm{t}$-statistics difference in means and regression analysis.

\section{Identification of an acquirer's corporate life cycle stage}

To identify LCO stages of acquiring firms, the Dickinson (2011) methodology was applied [6]. This approach assumes that all companies' important activities are captured in three different types of cash flows - operating, financing and investing. Thus, an acquirer's lifecycle stage is identified based on the signs of its cash flows at the reporting date prior to the deal announcement, in correspondence with Table 1.

Table 1. Corporate life cycle stage identification rules based on the signs of cash flows

\begin{tabular}{|c|c|c|c|c|c|c|c|c|}
\hline & Introduction & Growth & Mature & \multicolumn{3}{|c|}{ Shake-Out } & \multicolumn{2}{|c|}{ Decline } \\
\hline Operating CF & - & + & + & - & + & + & - & - \\
\hline Investing CF & - & - & - & - & + & + & + & + \\
\hline Financing CF & + & + & - & - & + & - & + & - \\
\hline
\end{tabular}

Source: [6]. 
Table 2. Variables description

$\begin{array}{lll}\begin{array}{l}\text { Variable Type } \\ \text { Dependent variable }\end{array} & \text { CAR } & \text { Description } \\ \begin{array}{l}\text { Cumulative abnormal return for a deal over event window }(-1,+1)^{\mathrm{I}} \\ \begin{array}{l}\text { Explanatory main } \\ \text { variable }\end{array}\end{array} & \text { LCS Intro } & 1 \text { if an acquirer is at Introduction stage, } 0 \text { otherwise }\end{array}$

Explanatory main
variable $\quad$ LCS Growth 1 if an acquirer is at Growth stage, 0 otherwise

\begin{tabular}{|c|c|c|}
\hline $\begin{array}{l}\text { Explanatory main } \\
\text { variable }\end{array}$ & LCS Maturity & 1 if an acquirer is at Maturity stage, 0 otherwise \\
\hline Control variable & Target type & 1 if a target is private, 0 otherwise \\
\hline Control variable & Method of payment & 1 if method of payment is total cash, 0 otherwise \\
\hline Control variable & Industry relatedness & 1 if a deal is a focusing one, 0 otherwise \\
\hline
\end{tabular}

Control variable Acquirer's size $\quad \begin{aligned} & \text { Natural logarithm of acquirer's assets for the last reporting date } \\ & \text { before the deal announcement moment }\end{aligned}$

$\begin{array}{lrl}\text { Control variable } & \text { Acquirer's ROA } & \begin{array}{l}\text { Acquirer's net income / Acquirer's assets for the last reporting date } \\ \text { before the deal announcement moment }\end{array} \\ \text { Control variable } & \text { Relative deal size } & \begin{array}{l}\text { Deal value / Acquirer's assets for the last reporting date before the } \\ \text { deal announcement moment }\end{array} \\ \text { Control variable } & \text { Financial advisor }\end{array}$

\section{Identification of a deal type - mega or non-mega deal}

In most studies, mega deals are defined as those which are priced over $\$ 500 \mathrm{mln}-\$ 1 \mathrm{bln}$ [4]. Following this approach and taking into account that the United States market is the biggest M\&A market, we assume that the threshold for a mega deal is $\$ 1 \mathrm{bln}$. Thus, all deals with a value under $\$ 1$ bln are treated as non-mega deals while all deals with a value equal to or higher than $\$ 1$ bln are treated as mega deals.

\section{Estimation of CARs}

To assess the performance of M\&A deals over different LCO stages a standard event study method is employed. The market model is used for the purpose of CARs estimation. Firstly, predicted (or "normal") returns should be estimated - for this purpose, the alpha and beta for the market model are estimated based on the data for the window $(-250,-21)$ relative to the day of the deal announcement (day 0) in line with Craninckx and Huyghebaert (2011) [19]. Then, the estimated alpha and beta are applied to the market returns during the event window to get normal returns for the acquirer's stock. The next step is comparison of normal returns and actual returns - the difference between these returns is called “abnormal returns”. Finally, abnormal returns over all days inside the event window are added together to get cumulative abnormal returns (CARs). CARs are calculated for different event windows to provide the results' robustness check: $(-1,+1),(-5,+5),(-1,+5),(-10,+10),(-1,+10)$ in line with the work of previous researchers [20, 21, 22, 23]. Formally, the estimation steps are as follows:

Estimation of the market model:

$\mathrm{R}_{\mathrm{jt}}=\alpha_{\mathrm{j}}+\beta_{\mathrm{j}} \mathrm{R}_{\mathrm{mt}}+\varepsilon_{\mathrm{j}},(1)$

where $\alpha_{\mathrm{j}}$ - intercept;

$\beta_{\mathrm{j}}$ - coefficient that expresses stock's volatility relative to the market return;

$\mathrm{R}_{\mathrm{mt}}$ - market return at day $\mathrm{t}$;

$\mathrm{R}_{\mathrm{jt}}$ - acquirer's stock return at day $\mathrm{t}$;

$\mathrm{t}$ - a day from the estimation window, $\mathrm{j}$ - the acquirer. The output of this estimation is $\hat{\alpha}_{\mathrm{j}}$ and $\hat{\beta}_{\mathrm{j}}$.

Calculation of predicted returns:

$\hat{\mathrm{R}}_{\mathrm{j} \tau}=\hat{\alpha}_{\mathrm{j}}+\hat{\beta}_{\mathrm{j}} \mathrm{R}_{\mathrm{m} \tau}+\varepsilon_{\mathrm{j}},(2)$

where $\hat{\alpha}_{\mathrm{j}}$ and $\hat{\beta}_{\mathrm{j}}$ - estimators from step one;

$\tau$ - a day from event window.

${ }^{I}$ CARs for all event windows from the previous step are used as dependent variables for the purpose of a robustness check. The regression results presented in the paper are related to $(-1,+1)$ event windows. 
Calculation of abnormal returns:

$\mathrm{AR}_{\mathrm{j} \tau}=\mathrm{R}_{\mathrm{j} \tau}-\hat{\mathrm{R}}_{\mathrm{j} \tau}$.(3)

Calculation of average abnormal returns for a day:

$\overline{\mathrm{AR}_{\hat{\mathrm{o}}}}=\mathrm{AR}_{\mathrm{jô}} / \mathrm{N}_{\mathrm{j}},(4)$

where $\mathrm{N}_{\mathrm{j}}$ - number of deals (acquirers).

Calculation of cumulative abnormal returns:

$\mathrm{CAR}=\sum_{\tau} \overline{\mathrm{AR}_{\tau}} \cdot(5)$

Then, CAR is checked for significance by means of a standard t-test.

\section{Comparative analysis}

To compare deals' performance between stages, we calculate the differences between pairs of CARs, estimated for different LCO stages, and check the significance of this difference using the t-statistics difference in means, and also employ a regression analysis, using the following model:

$\operatorname{CAR}_{\mathrm{i}}=\beta_{0}+\beta_{1} \cdot$ LCS Intro $_{\mathrm{i}}+\beta_{2} \cdot$ LCS Growth $_{\mathrm{i}}+$ $+\beta_{3} \cdot$ LCS Maturity ${ }_{\mathrm{i}}+\beta_{4} \cdot$ Target type $_{\mathrm{i}}+$

$+\beta_{5} \cdot$ Method of payment ${ }_{\mathrm{i}}+\beta_{6} \cdot$ Industry relatedness $_{\mathrm{i}}+$.(6)

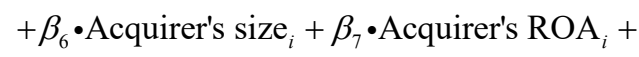

$+\beta_{8} \cdot$ Relative deal size $_{i}+\beta_{9} \cdot$ Financial advisor $_{\mathrm{i}}+\varepsilon_{i}$

The dependent variable is cumulative abnormal return (CAR) for a single deal, which is explained by the set of independent variables, which are several dummy variables as indicators of life cycle stage and standard controls. To capture relative deals performance over appropriate stages, we introduce simultaneously three dummy variables to represent the introduction, growth and maturity stages, showing the effect relative to the decline stage, taken as a base. A description of the variables is provided in Table 2.

\section{Sample}

The sample gathered for current research consists of domestic US M\&A deals. The choice of the United States market can be explained by the fact that this market represents almost a half of the global M\&A market in terms of deals value as of $2017^{1}$. As for mega deals in particular, US mega M\&As represent more than 50\% of the total number of mega M\&As around the world, as of $2016^{2}$. The focus on domestic deals arises from the fact that cross-border and domestic deals are different in their nature, as there is a separate field of M\&A research that analyses these differences.
The timeframe of the deals is between 2003 and 2017, with the exclusion of the crisis period between 2008 and 2009. The crisis period is excluded as stocks' price dynamics during that period reflect crisis shocks, so it is quite difficult to eliminate these shocks in stock data to receive results which are comparable with standard non-crisis periods.

We use the Capital IQ, Bloomberg and Thomson Reuters Eikon databases to identify an initial sample of publicly traded deals that fit into the categories of complete transactions over 2003-2017. We further require that (1) a deal results in acquisition of the majority stake - at least $50 \%+$ 1 , (2) both an acquirer and a target are not from the financial or utilities sectors - exclusion is based on SIC codes (6000-6999 for financial companies and 4900-4999 for utilities firms) [13], (3) an acquirer is a public company while a target might be either a public or a private one, (4) total transaction value is higher than $\$ 50 \mathrm{mln}$ [24].

Our requirements yield the sample of 2,413 US domestic deals. The sample's mean deal value is $\$ 990 \mathrm{mln}$ with a maximum of approximately $\$ 97 \mathrm{bln}$. The average relative deal size in the sample is approximately $28 \%$. The average acquirer would have about $\$ 15$ bln of assets and return on these assets equal to $5.5 \%$. There are 78 deals in which an acquirer is at the introduction lifecycle stage, 763 deals with a growing acquirer, 1,345 deals with a mature acquirer, and 227 with a declining acquirer ${ }^{3}$.

Table 3 summarises distribution over categories for category variables. Based on the data from Table 3, it can be stated that the median deal would be a friendly one where a private target from a related industry is acquired by paying otherwise than with cash.

Table 3. Number of observations distribution over category variables

\begin{tabular}{lc} 
Category & Number of observations \\
Deal attitude & \\
Friendly & 2406 \\
\hline Hostile & 7 \\
Target type & 2362 \\
\hline Private & 51
\end{tabular}

Payment type

Not total cash $\quad 2027$

Total cash $\quad 386$

\footnotetext{
${ }^{1}$ Based on the data of IMAA Institute, in 2017 the total value of US deals equaled to $\$ 1716$ bln, while worldwide deal value was $\$ 3,591$ bln in total. Link: imaa-institute.org.

${ }^{2}$ Based on the data of IMAA Institute, in 2016 the total worldwide number of mega deals equaled 590 deals. Based on the data of the statistical portal Statista, in 2016 the total number of US mega deals equaled 316. Link: imaa-institute.org, statista.com

${ }^{3}$ Based on the available information we were able to identify four life cycle stages (introduction, growth, maturity, decline) instead of five, as suggested by Dickinson (2011) [6].
} 


\section{Category Number of observations}

Industry relatedness

\begin{tabular}{|c|c|}
\hline Related & 1261 \\
\hline Not related & 1152 \\
\hline
\end{tabular}

Source: authors' estimation.

Table 4 represents the distribution of the sample based on two factors - acquirer's corporate life cycle stage, and the fact of whether a deal is a mega or a non-mega one. The distribution is close to the one we would expect: the least popular life cycle stage is the introduction stage as we analyse only public acquirers and most introductory companies are not public yet. Almost $85 \%$ of the deals are non-mega deals - one might expect this share to be even higher but in our case it is affected by the initial requirement for the deal size to be $\$ 50 \mathrm{mln}$.

\section{Results}

As outlined above, the first step of analysis is an estimation of cumulative abnormal returns (CARs) over lifecycle stages. CARs for the whole sample, subsamples of mega deals and non-mega deals are presented in Table 5. As can be seen from the results, acquirers achieve positive and significant (at $1 \%$ level) returns on average, however, these returns are quite low - slightly below $1 \%$ for all event windows. While analysing mega deals and non-mega deals separately, it can be seen that investors evaluate non-mega deals better - CARs for non-mega deals are two times higher compared to the results for mega deals. The difference between CARs for mega and non-mega deals subsamples were checked for significance by t-test. Differences for all five pairs for different event windows are significant at a $5 \%$ level. Thus, Hypothesis 1 cannot be rejected at a $5 \%$ significance level. These results are in line with the previous research on mega vs. non-mega deals $[4 ; 5]$.

Table 4. Distribution of the number of observations over corporate life cycle stages and mega-non-mega deals

\begin{tabular}{|c|c|c|c|}
\hline Corporate life cycle stages & Mega deals & Non-mega deals & Total \\
\hline Introduction & 4 & 74 & 78 \\
\hline Growth & 106 & 657 & 763 \\
\hline Maturity & 247 & 1098 & 1345 \\
\hline Decline & 29 & 198 & 227 \\
\hline Total & 386 & 2027 & 2413 \\
\hline
\end{tabular}

Source: authors' estimation.

Table 5. CARs for the full sample, subsamples of mega and non-mega deals for different event windows

\begin{tabular}{|c|c|c|c|}
\hline & Full sample & Mega deals & Non-mega \\
\hline \multirow{2}{*}{$(-1,+1)$} & $0.98 \%^{* * *}$ & $0.57 \%^{\star * *}$ & $1.05 \%^{* * * b)}$ \\
\hline & $(0.00 \%)$ & $(0.00 \%)$ & $(0.00 \%)$ \\
\hline \multirow{2}{*}{$(-5,+5)$} & $0.96 \%$ *** & $0.46 \%$ ** & $1.06 \%^{* * * b)}$ \\
\hline & $(0.00 \%)$ & $(3.94 \%)$ & $(0.00 \%)$ \\
\hline \multirow{2}{*}{$(-1,+5)$} & $0.93 \%^{* * *}$ & $0.46 \%$ ** & $1.02 \% * * * b)$ \\
\hline & $(0.00 \%)$ & $(1.30 \%)$ & $(0.00 \%)$ \\
\hline \multirow{2}{*}{$(-10,+10)$} & $1.00 \% \%^{\star * *}$ & $0.46 \%$ & $1.10 \%^{* * * b)}$ \\
\hline & $(0.00 \%)$ & $(10.05 \%)$ & $(0.00 \%)$ \\
\hline \multirow{2}{*}{$(-1,+10)$} & $0.93 \%^{* * *}$ & $0.42 \%^{*}$ & $1.03 \%^{* * * b)}$ \\
\hline & $(0.00 \%)$ & $(6.32 \%)$ & $(0.00 \%)$ \\
\hline $\mathrm{N}$ & 2413 & 386 & 2027 \\
\hline
\end{tabular}

$* * *, * *{ }^{*}$ - Significance at $1 \%, 5 \%, 10 \%$ levels;

a), b), c) - Significance at 1\%, 5\%, 10\% levels - when checking the differences between CARs for mega and non-mega deals;

$\mathrm{N}$ - number of observations;

$\mathrm{p}$-value in parentheses. 
Table 6. CARs for the full sample across lifecycle stages for different event windows

\begin{tabular}{|c|c|c|c|c|}
\hline \multirow{2}{*}{$(-1,+1)$} & $1.32 \%^{* *}$ & $1.36 \%^{\star * *}$ & $0.82 \%^{* * * c)}$ & $0.32 \%^{c)}$ \\
\hline & $(3.08 \%)$ & $(0.00 \%)$ & $(0.00 \%)$ & (12.88\%) \\
\hline \multirow{2}{*}{$(-5,+5)$} & $2.89 \%^{\star *}$ & $1.22 \%^{* * *}$ & $0.78 \%^{\star * * c)}$ & $0.51 \%{ }^{c)}$ \\
\hline & $(1.61 \%)$ & $(0.00 \%)$ & $(0.00 \%)$ & $(17.83 \%)$ \\
\hline \multirow{2}{*}{$(-1,+5)$} & $2.80 \%^{\star * \star}$ & $1.20 \% \%^{\star * *}$ & $0.74 \%^{* * * c)}$ & $0.50 \%{ }^{c)}$ \\
\hline & $(0.47 \%)$ & $(0.00 \%)$ & $(0.00 \%)$ & $(12.76 \%)$ \\
\hline \multirow{2}{*}{$(-10,+10)$} & $3.07 \%^{* *}$ & $1.22 \%^{* * *}$ & $0.84 \%^{\star * * c)}$ & $0.51 \%^{\mathrm{c})}$ \\
\hline & $(4.95 \%)$ & $(0.02 \%)$ & $(0.03 \%)$ & $(24.92 \%)$ \\
\hline \multirow{2}{*}{$(-1,+10)$} & $3.05 \%^{* *}$ & $1.15 \%^{* * *}$ & $0.75 \%^{\star * * c)}$ & $0.50 \%{ }^{c)}$ \\
\hline & $(1.54 \%)$ & $(0.00 \%)$ & $(0.00 \%)$ & (18.97\%) \\
\hline $\mathbf{N}$ & 78 & 763 & 1345 & 227 \\
\hline
\end{tabular}

${ }_{* * *}^{* *},{ }^{\star}-$ Significance at $1 \%, 5 \%, 10 \%$ levels;

a), b), c) - Significance at 1\%, 5\%, 10\% levels - when checking the differences between CARs for different LCO stages; $\mathrm{N}$ - number of observations; p-value in parentheses.

Figure 1. CARs of acquirers for period $(-21,+21)$ for all deals, mega deals and non-mega deals

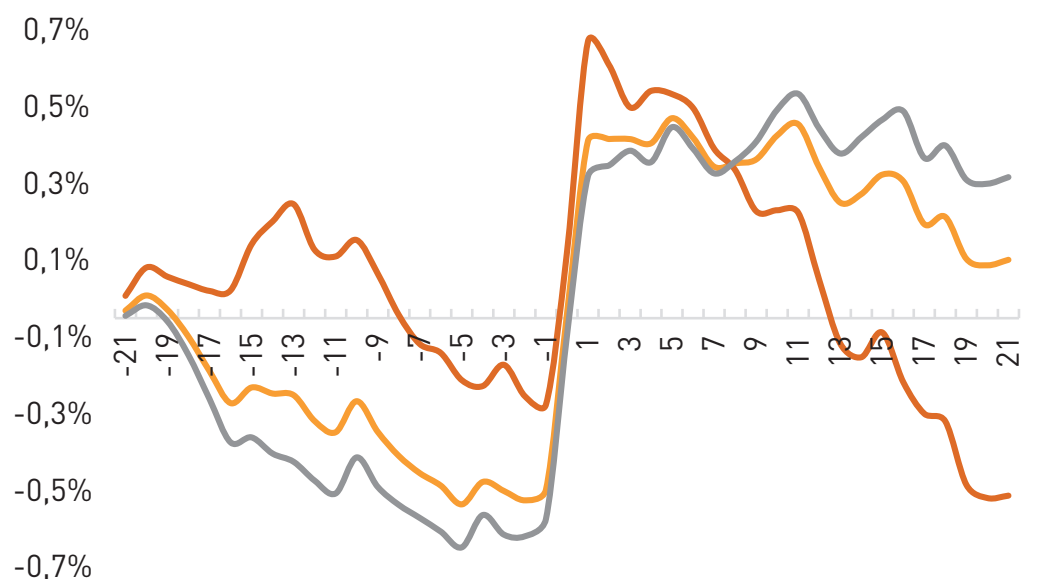

$-0,7 \%$

All deals Mega deals Non-mega deals

Figure 1 illustrates how CARs change over the period from 21 days before the announcement till 21 days after the announcement for all deals, and separately for mega and non-mega ones. There is an immediate jump in the moment of announcement for all deals, both mega and non-mega ones which suggests that the market had not been learning about the deals before the announcement. One more insight from the picture is that mega deals experience a much greater decline in CARs after the moment of announcement.

In Table 6 below we show CARs for the full sample across different lifecycle stages - introduction, growth, maturity and decline. From the full sample analysis we can see that CARs decrease on average over the lifecycle of an organ- isation, which is in line with the findings provided by Owen and Yason (2010) and Arikan and Stulz (2016) [1; 2]. At the first three lifecycle stages CARs are positive and significant at least at a 5\% level of significance, while CARs that acquirers receive while being at the stage of decline are not significantly different from zero. The pairs of CARs that are compared with each other were also checked for the significance of difference between them, using the t-statistics difference in means. The results suggest that differences between CARs at growth and maturity stages and differences between CARs at maturity and decline stages are significant at a $10 \%$ level. Thus, Hypothesis 2.1 is rejected at a 10\% significance level and Hypotheses 2.2 and 2.3 cannot be rejected at a $10 \%$ significance level. 
Table 7. CARs for mega and non-mega deals subsample across lifecycle stages for different event windows

\begin{tabular}{|c|c|c|c|c|c|c|c|c|}
\hline & \multicolumn{4}{|c|}{ Mega deals } & \multicolumn{4}{|c|}{ Non-mega deals } \\
\hline & Introduction & Growth & Maturity & Decline & Introduction & Growth & Maturity & Decline \\
\hline \multirow{2}{*}{$(-1,+1)$} & $-7.58 \%$ *** & $0.78 \%^{* * * b)}$ & $0.56 \%^{* * *}$ & $1.13 \%^{* *}$ & $1.76 \%^{* * * b)}$ & $1.46 \%^{* * * b)}$ & $0.88 \%^{* * * b)}$ & $0.21 \%^{\mathrm{b})}$ \\
\hline & $(0.00 \%)$ & $(0.30 \%)$ & $(0.02 \%)$ & $(2.81 \%)$ & $(0.89 \%)$ & $(0.00 \%)$ & $(0.00 \%)$ & $(25.07 \%)$ \\
\hline \multirow{2}{*}{$(-5,+5)$} & $-11.87 \%^{* * *}$ & $0.88 \%^{* * * b)}$ & $0.45 \%^{* * *}$ & $1.14 \%^{* *}$ & $3.62 \%^{* * * b)}$ & $1.28 \%^{* * * b)}$ & $0.86 \%^{* * * b)}$ & $0.42 \%^{* b)}$ \\
\hline & $(0.00 \%)$ & $(0.11 \%)$ & $(0.18 \%)$ & $(2.75 \%)$ & $(0.00 \%)$ & $(0.00 \%)$ & $(0.00 \%)$ & $(9.20 \%)$ \\
\hline \multirow{2}{*}{$(-1,+5)$} & $-11.87 \%^{* * *}$ & $0.94 \%^{* * * b)}$ & $0.44 \%^{* * *}$ & $1.11 \%^{* *}$ & $3.53 \%^{* * * b)}$ & $1.24 \%^{\star * * b)}$ & $0.80 \%^{* * * b)}$ & $0.41 \%^{* b)}$ \\
\hline & $(0.00 \%)$ & $(0.05 \%)$ & $(0.24 \%)$ & $(3.07 \%)$ & $(0.00 \%)$ & $(0.00 \%)$ & $(0.00 \%)$ & $(9.44 \%)$ \\
\hline \multirow{2}{*}{$(-10,+10)$} & $-11.87 \%^{* * *}$ & $0.87 \%^{* * * b)}$ & $0.45 \%^{* * *}$ & $1.26 \%^{* *}$ & $3.81 \%^{* * * b)}$ & $1.28 \%^{* * * b)}$ & $0.93 \%^{* * * b)}$ & $0.41 \%^{* b)}$ \\
\hline & $(0.00 \%)$ & $(0.12 \%)$ & $(0.21 \%)$ & $(1.70 \%)$ & $(0.00 \%)$ & $(0.00 \%)$ & $(0.00 \%)$ & $(9.66 \%)$ \\
\hline \multirow{2}{*}{$(-1,+10)$} & $-11.87 \%^{* * *}$ & $0.85 \%^{* * * b)}$ & $0.40 \%^{* * *}$ & $1.15 \%^{* *}$ & $3.78 \%^{* * * b)}$ & $1.20 \%^{* * * b)}$ & $0.83 \%^{* * * b)}$ & $0.41 \%^{* b)}$ \\
\hline & $(0.00 \%)$ & $(0.14 \%)$ & $(0.54 \%)$ & $(2.63 \%)$ & $(0.00 \%)$ & $(0.00 \%)$ & $(0.00 \%)$ & $(9.41 \%)$ \\
\hline N & 4 & 106 & 247 & 29 & 74 & 657 & 1098 & 198 \\
\hline
\end{tabular}

${ }^{* * *},{ }^{* *},{ }^{*}$ - Significance at $1 \%, 5 \%, 10 \%$ levels;

a), b), c)-Significance at 1\%, 5\%, 10\% levels - when checking the differences between CARs for different LCO stages for mega and non-mega deals; $\mathrm{N}$ - number of observations; $\mathrm{p}$-value in parentheses.

Table 8. Regression analysis results for the subsamples of mega and non-mega deals

\begin{tabular}{|c|c|c|}
\hline & $\begin{array}{l}\text { Model (6) } \\
\text { mega deals }\end{array}$ & $\begin{array}{c}\text { Model (6) } \\
\text { non-mega deals }\end{array}$ \\
\hline LSC: Introduction & $-0.1051^{* * *}$ & 0.0095 \\
\hline LSC: Growth & -0.0111 & $0.0123^{* * *}$ \\
\hline LSC: Mature & -0.0013 & $0.0092^{\star \star}$ \\
\hline Target type & 0.0164 & $0.0191^{\star}$ \\
\hline Method of payment & 0.0079 & 0.0014 \\
\hline Industry relatedness & 0.0013 & 0.0004 \\
\hline Acquirer size & $-0.0091^{\star * *}$ & $-0.0022^{\star *}$ \\
\hline Acquirer ROA & $-0.1303^{\star \star}$ & $0.0324^{\star \star}$ \\
\hline Relative deal size & -0.0082 & $0.0194^{* * *}$ \\
\hline Financial advisor & 0.1087 & 0.0038 \\
\hline (Intercept) & $0.1085^{\star \star \star}$ & 0.0081 \\
\hline $\mathrm{N}$ & 386 & 2027 \\
\hline R-squared & 0,06 & 0,04 \\
\hline F-statistics & $2,17^{* * *}$ & $8,58^{* * *}$ \\
\hline
\end{tabular}

${ }^{* * *},{ }^{* *},{ }^{*}-$ Significance at $1 \%, 5 \%, 10 \%$ levels;

$\mathrm{N}$ - number of observations. 
If the full sample is divided into subsamples of mega and non-mega deals (see Table 7), we get different results for them. In mega deals, acquiring firms receives negative returns at the introduction LCO stage and positive returns at all other stages, while in non-mega deals acquiring shareholders get benefits from M\&As at all LCO stages. The results also indicate that non-mega deals outperform mega ones at introduction and growth stages. It is obvious that acquirers at the introduction stage experience negative returns when being engaged in mega M\&As while non-mega deals bring positive returns. This can be explained by the fact that engagement in M\&A deals while being at introduction stage is perceived by investors as too aggressive and risky strategy. Thus, our hypotheses 3.1-4.2 and 5.2 are not rejected at a 1\% level, hypothesis 5.1 is rejected at a $1 \%$ level, and our tested hypotheses 6.1 and 6.2 are not rejected at $5 \%$ and $10 \%$ levels correspondingly.

We further compare the performance of M\&As between stages for mega and non-mega transactions separately. We capture this effect by firstly using the t-statistics difference in means to check the significance of differences between pairs of CARs at various LCO stages, and secondly, by introducing three dummy variables for the introduction, growth and mature stages, taking the decline stage as a base in model (6).Our results for mega deals (tables 7, 8) show that there is a statistically significant difference only between introduction and growth stage CARs (at 5\% level) and introduction and decline stage CARs (at 1\% level), indicating that acquirers at introduction stage perform relatively badly in comparison with bidders at growth and decline stages. For non-mega deals (Tables 7,8 ) we find a statistically significant difference between growth and maturity stage CARs, maturity and decline stage CARs (at 5\% level) and growth and decline stage CARs (at $1 \%$ level). Thus, we may conclude that the general tendency of CARs to decrease across all lifecycle stages stays in place for non-mega acquisitions.

\section{Conclusion}

This paper assesses the impact of an acquirer's corporate LCO stages on the performance of M\&A deals. Our research is motivated by the increasing interest in the theory of the lifecycle of organisation (LCO), which proposes that a firm's LCO stage dramatically influences all the firm's crucial strategic decisions, among which is the decision to be engaged in M\&As $[25,26]$. Our review of existing empirical studies indicates that acquirers LCO stage can have a potential impact on M\&A performance and its drivers. However, the literature is scarce, indicating the need for further research.

In contrast to previous studies, we analyse differences in the effect of LCO stages on M\&A performance for non-mega and mega deals, which have become a popular phenomenon in last years. We also separate the acquirer's life cycle into four stages, whereas the previous studies mostly focus on three stages.
Based on a sample of 2,413 US domestic M\&As deals over the years 2003-2017, and subsamples of mega (386) and non-mega (2027) deals, we find that the stock market reaction is positive for $\mathrm{M} \& \mathrm{~A}$ deals, and this reaction is more favourable for non-mega acquisitions than for mega M\&As. These outcomes do not contradict the findings of Alexandridis et al. $(2010,2013)$ [4; 5]. Our results also indicate that CARs decrease on average with the lifecycle of an organisation for the full sample, which supports the findings provided by Owen, Yawson (2010) and Arikan, Stulz (2016) [1;2]. However, if the full sample is divided into subsamples of mega and non-mega deals, the general tendency of CARs to decrease across LCO stages persists only for non-mega transactions. But at all LCO stages, acquirers' shareholders will receive positive returns, while in mega M\&As bidders' shareholders gain only at the growth, mature and declining stages.

Overall, our findings reveal that M\&A deals affect acquirers' returns differently depending on bidder LCO stage and the type of deal, i.e. whether it is a mega or non-mega one. These results can be used as a practical guide for managers making investment decisions. They will help managers to justify a company's expansion via mega and non-mega deals, taking into account companies LCO stages.

While we obtain significant results, they are valid with regard to several limitations. First, we concern ourselves only with the developed US market. Secondly, we concentrate only on domestic M\&As. Finally, this study explores short-term effects, which does not allow for the extrapolation of conclusions regarding long-term periods. Thus we suggest for further research to explore the effects of LCO stages on M\&A performance for companies from other developed and emerging capital markets that are engaged in domestic and cross-border deals over short and long-term periods. We also suggest examining the impact of bidders' LCO stages in mega and non-mega deals on M\&A performance for the periods before and after the global financial crisis of 2007-2008, due to enhancements in corporate governance culture in the subsequent period.

\section{References}

1. Owen S., Yawson A. Corporate life cycle and M\&A activity. Journal of Banking \& Finance. 2010;34(2):427-440. DOI: 10.1016/j. jbankfin.2009.08.003

2. Arikan A.M., Stulz R.M. Corporate acquisitions, diversification, and the firm's life cycle. The Journal of Finance. 2016;71(1):139-194. DOI: 10.1111/jofi.12362

3. Chuang K.-S. Corporate life cycle, investment banks and shareholder wealth in M\&As. The Quarterly Review of Economics and Finance. 2017;63:122-134. DOI: 10.1016/j.qref.2016.02.008

4. Alexandridis G., Petmezas D., Travlos N.G. Gains from mergers and acquisitions around the world: New evidence. Financial Management. 2010;39(4):1671-1695. DOI: 10.2307/40963524 
5. Alexandridis G., Fuller K.P., Terhaar L., Travlos N.G. Deal size, acquisition premia and shareholder gains. Journal of Corporate Finance. 2013;20:1-13. DOI: 10.1016/j.jcorpfin.2012.10.006

6. Dickinson V. Cash flow patterns as a proxy for firm life cycle. The Accounting Review. 2011;86(6):19691994. DOI: $10.2308 /$ accr- 10130

7. Faff R., Kwok W.C., Podolski E.J., Wong G. Do corporate policies follow a life-cycle? Journal of Banking \& Finance. 2016;69:95-107. DOI: 10.1016/j. jbankfin.2016.04.009

8. Jovanovic B. Selection and the evolution of industry. Econometrica. 1982;50(3):649-670. DOI: DOI: $10.2307 / 1912606$

9. Barclay M.J., Smith C.W. The capital structure puzzle: The evidence revisited. Journal of Applied Corporate Finance. 2005;17(1):8-17. DOI: 10.1111/j.17456622.2005.012_2.x

10. Spence A.M. The learning curve and competition. The Bell Journal of Economics. 1981;12(1):49-70. DOI: DOI: $10.2307 / 3003508$

11. Davis G.F., Stout S.K. Organization theory and the market for corporate control: A dynamic analysis of the characteristics of large takeover targets, 1980-1990. Administrative Science Quarterly. 1992;37(4):605-633. DOI: 10.2307/2393474

12. Hannan M.T., Freeman J. Structural inertia and organizational change. American Sociological Review. 1984;49(2):149-164. DOI: 10.2307/2095567

13. Partin I.M., Vasin A.D. The influence of corporate life cycle on M\&A activity of the company in developing capital markets. Korporativnye finansy $=$ Journal of Corporate Finance Research. 2014;8(3):23-37. (In Russ.). DOI: 10.17323/j.jcfr.2073-0438.8.3.2014.23-37

14. Saigol L. Big deals are bad for everyone - almost. Financial Times. Sept. 18, 2015. URL: https:// www.ft.com/content/c740d8b6-5d47-11e5-9846de406ccb37f2

15. M\&A mega deals surge. Quarterly Deal Performance Monitor: Q2 2016. Willis Towers Watson. URL: https://www.macouncil.org/blog/2016/08/29/mamega-deals-surge

16. Alexandridis G., Antypas N., Travlos N. Value creation from M\&As: New evidence. Journal of Corporate Finance. 2017;45:632-650. DOI: 10.1016/j. jcorpfin.2017.05.010

17. Alexandridis G., Antypas N., Travlos N. Smart mega-merger deals: Value creation on a massive scale. EFMA. 2017. URL: https://efmaefm. org/0EFMAMEETINGS/EFMA\%20ANNUAL\%20 MEETINGS/2017-Athens/papers/EFMA2017_0596_ fullpaper.pdf
18. Dahya J., Golubov A., Petmezas D., Travlos N. Governance mandates, outside directors, and acquirer performance. Journal of Corporate Finance. 2016. DOI: 10.1016/j.jcorpfin.2016.11.005

19. Craninckx K., Huyghebaert N. Can stock markets predict M\&A failure? A study of European transactions in the fifth takeover wave. European Financial Management. 2011;17(1):9-45. DOI: 10.1111/j.1468-036X.2010.00541.x

20. Campa J.M., Hernando I. Shareholder value creation in European M\&As. European financial management. 2004;10(1):47-81. DOI: 10.1111/j.1468036X.2004.00240.x

21. Grigorieva S.A., Morkovin R. The effect of crossborder and domestic acquisitions on shareholder wealth: evidence from BRICS acquirers.

Korporativnye finansy = Journal of Corporate Finance Research. 2014;8(4):34-45. DOI: 10.17323/j.jcfr.20730438.8.4.2014.34-45

22. Kiymaz H., Baker H.K. Short-term performance, industry effects, and motives: evidence from large M\&As. Quarterly Journal of Finance and Accounting. 2008;47(2):17-44.

23. Papadakis V.M., Thanos I.C. Measuring the performance of acquisitions: An empirical investigation using multiple criteria. British Journal of Management. 2010;21(4):859-873. 10.1111/j.14678551.2009.00671.x

24. Walker M.M. Corporate takeovers, strategic objectives, and acquiring-firm shareholder wealth. Financial Management. 2000;29(1):53-66. DOI: $10.2307 / 3666361$

25. Castro P., Fernández M.T.T., Amor-Tapia B., de Miguel A. Target leverage and speed of adjustment along the life cycle of European listed firms. BRQ Business Research Quarterly. 2016;19(3):188-205. DOI: 10.1016/j.brq.2016.01.003

26. Yazdanfar D., Öhman P. Capital structure dynamics among SMEs: Swedish empirical evidence. The Journal of Risk Finance. 2016;17(2):245-260. DOI: 10.1108/JRF-04-2015-0040 